\title{
EKOGŁASNOST I EKOTRANSFORMACJA. BUŁGARSKI RUCH EKOLOGICZNY W PIERWSZYCH LATACH TRANSFORMACJI USTROJOWEJ
}

\author{
TADEUSZ CZEKALSKI
}

\begin{abstract}
Ekoglasnost and Eco-transformation. Bulgarian Environmental Movement in the First Years of the Political Transformation.

The article discusses the origin and development of the ecological movement in Bulgaria in the first period of political transformation, against the background of similar experiences of Balkan countries. In the Balkan reality, the social activity of ecological groups is perceived as an example of the penetration of Western European cultural patterns, but also as an effect of "ecological pressure" resulting from the aspirations of South-Eastern European countries to integrate with European structures. To a small extent, the contemporary ecological sensitivity of the inhabitants of the Balkans refers to earlier experiences, such as those from the first decade of the political transformation. Against this background, the birth of the "indigenous" ecological movement in Bulgaria and its significant participation in the downfall of Todor Zhivkov's regime can be considered an exceptional phenomenon.
\end{abstract}

STRESZCZENIE. Artykuł omawia powstanie i rozwój ruchu ekologicznego w Bułgarii w pierwszym okresie transformacji ustrojowej, na tle podobnych doświadczeń państw bałkańskich. W bałkańskich realiach społeczna aktywność ugrupowań ekologicznych jest postrzegana jako przykład przenikania zachodnioeuropejskich wzorców kulturowych, ale także jako efekt „,presji ekologicznej” wynikającej z dążenia krajów Europy Południowo-Wschodniej do integracji ze strukturami europejskimi. W niewielkim stopniu współczesna wrażliwość ekologiczna mieszkańców Bałkanów odwołuje się do wcześniejszych doświadczeń, choćby tych z pierwszej dekady transformacji ustrojowej. Na tym tle zjawiskiem za zjawisko wyjątkowe można uznać narodziny ,,autochtonicznego" ruchu ekologicznego w Bułgarii, a także jego znaczący udział w procesie upadku reżimu Todora Żiwkowa.

Author: Tadeusz Czekalski, Uniwersytet Jagielloński w Krakowie, Instytut Historii, ul. Gołębia 13, 31-007 Kraków, Polska, e-mail: tadeusz.czekalski@uj.edu.pl, ORCID iD: https://orcid.org/0000-0002-8494-1769

Keywords: Balkan history, Bulgaria, ecology, political transformation, social movements

Słowa kluczowe: Bułgaria, historia Bałkanów, ekologia, transformacja ustrojowa, ruchy społeczne

Balcanica Posnaniensia. Acta et studia, XXVI, Poznań 2019, Wydawnictwo Instytutu Historii UAM, pp. 231247, ISBN 978-83-66355-32-3, ISSN 0239-4278. Polish text with summaries in English and Polish.

doi.org/10.14746/bp.2019.26.13 
Pojawiające się na kontynencie europejskim już pod koniec XIX w. organizacje, które w swojej misji społecznej koncentrowały się na idei ochrony środowiska naturalnego przed zagrożeniami cywilizacyjnymi pozostawały początkowo zjawiskiem elitarnym, kojarzonym ze środowiskami uniwersyteckimi i krajoznawczymi ${ }^{1}$. Upowszechnienie i umasowienie idei enwironmentalistycznych należy wiązać z pojawieniem się nowych form aktywności społecznej pod koniec lat 60. XX w., określanych pojęciem „nowych ruchów społecznych” (NRS). Nowe pokolenie społecznych aktywistów skupiało się nie tyle na problemach ekonomiczno-społecznych, co raczej na obronie praw człowieka i zagadnieniach tożsamościowych. W przeciwieństwie do scentralizowanych i zhierarchizowanych dawnych ruchów społecznych, NRS stanowiły rodzaj zdecentralizowanych sieci łączących grupy aktywistów, otwarcie demonstrujących postawy niechęci wobec tradycyjnych form aktywności społecznej i obywatelskiej ${ }^{2}$. Upowszechnienie nowych, niekonwencjonalnych metod działania przywoływało skojarzenia z ruchami studenckimi 1968 roku - okupacją miejsc publicznych, blokadą dróg, happeningami, ale także bezpośrednimi konfrontacjami z policją ${ }^{3}$. Organizacje ekologiczne, które stanowiły jeden z najbardziej aktywnych komponentów NRS w latach 70. korzystały także z typowych form komunikacji z ośrodkami władzy, działając poprzez akcje petycyjne, opracowywanie memoriałów, a także poprzez inicjatywy parlamentarne.

Przełomową rolę w kształtowaniu się masowych ruchów ekologicznych, a także zdobywaniu przez nich przestrzeni publicznej odegrała publikacja raportów, obrazujących konsekwencje rozwoju gospodarczego dla środowiska naturalnego, w tym szczególnie przejmującego dokumentu Limits to Growth, wydanego w 1972 r. przez Klub Rzymski, omawiającego zagrożenia wynikające $\mathrm{z}$ wyczerpywania się zasobów naturalnych Ziemi. W tym samym roku w Sztokholmie odbyła się międzynarodowa konferencja z udziałem europejskich przywódców politycznych poświęcona tematyce ochrony środowiska naturalnego. Rosnąca popularność ruchów ekologicznych wynikała z narastającego poczucia zagrożenia konsekwencjami nadmiernego uprzemysłowienia i rewolucji transportowej, ale zarazem stawała się konsekwencją wzrostu świadomości społeczeństwa, co do skutków zanieczyszczania powietrza i wód oraz masowej produkcji żywności ${ }^{4}$.

${ }^{1}$ W II połowie XIX w. w Wielkiej Brytanii powstało kilka organizacji, które w swojej działalności koncentrowały się na realizacji postulatów środowiskowych, by wspomnieć Commons Preservation Society (założoną w 1865 r.) czy też The Plumage League, powstałą w 1889 r. z inicjatywy Emily Williamson. Pojęcia ekologii po raz pierwszy miał użyć niemiecki biolog Ernst Haeckel w książce Generelle Morphologie, wydanej w 1866 r.; D. Maj, Ruch głębokiej ekologii, w: Nowe ruchy społeczne, red. M. Malczewska-Rytko, D. Maj, Lublin 2017, s. 72-73.

${ }^{2}$ H.A. van der Heijden, Social Movements, Public Spheres and the European Politics of the Environment Green Power Europe?, New York 2010, s. 20.

${ }^{3}$ R. Dalton, S. Reccia, R. Rohrschneider, The Environmental Movement and Modes of Political Action, "Comparative Political Studies" 2003, nr. 10, s. 1-29.

${ }^{4} \mathrm{~J}$. Burchell, The Evolution of Green Politics. Development and Change within European Green Parties, London 2002, s. 135-137. 
Obserwując ewolucję organizacji ekologicznych w Europie Zachodniej w latach 70. można zauważyć ich postępującą instytucjonalizację i internacjonalizację . Aktywność ekologiczna przestawała być wyłącznie domeną młodych aktywistów, wywodzących się ze środowisk studenckich, ale wpisywała się w zainteresowania i fascynacje przedstawicieli różnych grup społecznych, identyfikujących się z postulatami zdrowego stylu życia. Postulaty aktywnej ochrony środowiska naturalnego budowały znaczący kapitał polityczny, sprzyjając tworzeniu partii określanych pojęciem „environmental parties” (partie enwironmentalistyczne) albo „Green parties” (partie zielone). Podobnie jak w przypadku ruchów społecznych, także te ugrupowania polityczne zaliczano do kategorii nowych sił politycznych, odróżniających się od innych, tradycyjnych formacji politycznych. Według typologii amerykańskiego politologa Herberta Kitschelta, partie enwironmentalistyczne stanowiły organizmy o daleko idącym poziomie decentralizacji, w których preferowano zbiorowe podejmowanie decyzji, a kadrę partyjną tworzyły osoby, które lepiej definiowało pojęcie „aktywisty” niż „,złonka partii”" Andrzej Antoszewski wskazuje na funkcjonujący w zachodnioeuropejskiej nauce pogląd o partiach ekologicznych jako o ugrupowaniach niedających wpisać się w oś prawica-lewica, przez część badaczy uważanych nawet za swego rodzaju „antypartie"7. Europejskie „zielone partie” stały się beneficjentami znaczącej popularności w latach 80 . XX w., by w kolejnej dekadzie doświadczać spadku poparcia społecznego w rywalizacji z innymi ugrupowaniami politycznymi, które wzbogacały swoje programy wprowadzeniem do nich postulatów ekologicznych.

Pierwszym krajem Europy Południowo-Wschodniej, w którym pojawił się zorganizowany ruch ekologiczny była Grecja. Pierwsza organizacja ekologiczna w tym kra-

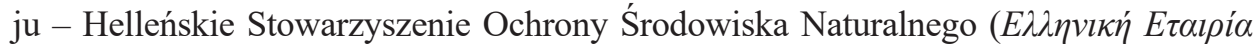

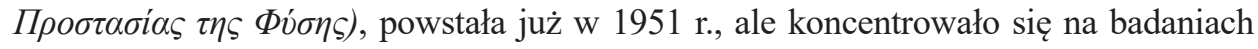
naukowych i działalności publicystycznej, trudno więc zaliczyć je do kategorii ruchów społecznych. Rozwój ruchu na rzecz ochrony środowiska został zablokowany w okresie dyktatury czarnych pułkowników, kiedy to działania pro-środowiskowe identyfikowano ze społecznym radykalizmem o podłożu lewicowym. Po upadku dyktatury, już w 1974 r. w życiu publicznym państwa greckiego pojawiło się szereg inicjatyw, w większości efemerycznych, identyfikujących się z postulatami enwironmentalistycznymi. W przeciwieństwie do krajów Europy Zachodniej, w których ugrupowania ekologiczne zdobyły znaczną popularność, Grecja nie doświadczała skutków intensywnego rozwoju przemysłu ciężkiego, czy też energetyki atomowej. Największym zagrożeniem dla mieszkańców Grecji wydawał się nefos (wielkomiejski smog), ale także postępujący proces erozji gleb i deforestacji. Inspiracją dla środowisk ekologicznych stały się

${ }^{5}$ H.A. van der Heijden, op. cit, s. 1-2.

${ }^{6}$ H. Kitschelt, The Green Phenomenon in Western Party Systems, w: Environmental Politics in the International Arena. Movements, Parties, Organizations and Policy, ed. Sh. Kamieniecki, New York 1993, s. 95-98.

${ }^{7}$ A. Antoszewski, Partie i systemy partyjne państw Unii Europejskiej na przetomie wieków, Toruń 2009, s. 194. 
też pierwsze lokalne protesty przeciwko zatruwaniu środowiska naturalnego przez zakłady chemiczne, do których doszło w 1976 r. w Missolungi, Salonikach i w Wolosie.

W toku kampanii przed wyborami parlamentarnymi 1981 r. socjalistyczna partia PASOK przedstawiła $\mathrm{w}$ swoim programie bogaty pakiet postulatów ekologicznych, w tym ochronę aglomeracji ateńskiej przed szkodliwym wpływem wielkich inwestycji przemysłowych, a także deklarację sprzeciwu wobec planów budowy w Grecji elektrowni atomowej. Wyborcze zwycięstwo PASOK przyniosło widoczny wzrost aktywności ugrupowań lewicowych i skrajnie lewicowych, które dostrzegały znaczenie potencjału politycznego programów środowiskowych ${ }^{8}$. Potwierdzała to aktywność nowych inicjatyw obywatelskich, jak ugrupowanie Obywatele przeciw-

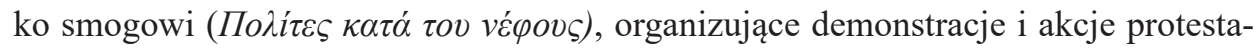
cyjne w Atenach, a także środowisk skupionych wokół "Dziennika Ekologicznego"

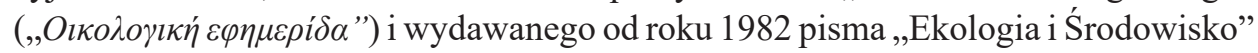

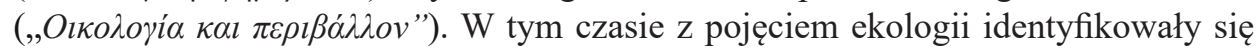
najczęściej niewielkie grupy dyskusyjne, zafascynowane kształtowaniem nowoczesnego stylu życia i właściwych relacji człowiek-przyroda 9 .

Rosnąca popularność ekologicznej retoryki sprzyjała zainteresowaniu greckimi wydaniami klasycznych prac Rachel Carson czy Henri Dumonta, ale nie przełożyła się na określony kapitał polityczny. Pierwsze próby tworzenia partii politycznej na wzór ,zielonych partii”, działających w Niemczech, we Włoszech czy Francji zakończyły się niepowodzeniem. Dopiero w październiku 1989 r., z inicjatywy dziennikarza Jorgosa Karabeliasa doszło do utworzenia Federacji Organizacji Ekologicznych

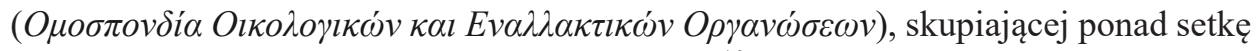
drobnych organizacji społecznych i politycznych ${ }^{10}$. W wyborach, które odbyły się zaledwie 40 dni po utworzeniu Federacji ekolodzy uzyskali poparcie $0.6 \%$ wyborców i jeden mandat w parlamencie. Nadmierne ambicje polityczne działaczy Federacji, ale także rozbieżności programowe przekreśliły jej szanse na sukces w kolejnych wyborach parlamentarnych ${ }^{11}$.

O ile w Grecji aktywność ruchu ekologicznego wpisywała się w przemiany polityczne po upadku dyktatury czarnych pułkowników, o tyle w pozostałych krajach bałkańskich ochrona środowiska naturalnego pozostawała w jaskrawej sprzeczności z ideą socjalistycznej industrializacji i nie była akceptowana jako dozwolona przez władze forma społecznej aktywności ${ }^{12}$. Sytuacja uległa zmianie dopiero pod koniec

8 J. Karamichas, Red and Green Facets of Political Ecology Accounting for Electoral Prospects in Greece, "Journal of Modern Greek Studies" 2008, t. 2008, nr. 2, s. 322.

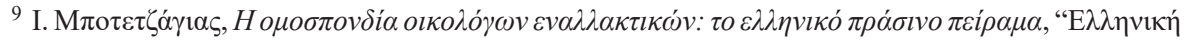

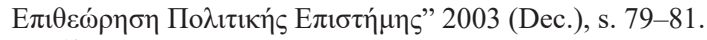

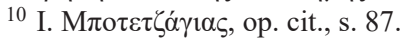

11 Federacja przetrwała do 1993 r.., a o jej upadku przesądził spór pomiędzy zwolennikami ,płytkiej” i ,głębokiej” ekologii - N. Demertzis, Greens at the Periphery, w: The Green Challenge. The development of Green parties in Europe, ed. D. Richardson, Ch. Roots, London \& New York 1995, s. 148.

12 P. Matczak, Problemy ekologiczne jako problemy społeczne, Poznań 2000, s. 95-96. 
lat 80. XX w., co stało się zarówno konsekwencją narastającego kryzysu społeczno-ekonomicznego, jak też postępującego procesu pluralizacji społeczeństwa.

Inspiracją dla protestów środowiskowych w komunistycznej Jugosławii stała się dyskusja na temat rozwoju energetyki jądrowej w tym kraju. Problem deficytu energetycznego częściowo udało się rozwiązać dzięki uruchomieniu w 1981 r. elektrowni atomowej w słoweńskim Krško. Plany budowy kolejnych tego rodzaju obiektów spotkały się z falą petycji kierowanych do Skupštiny, ale także protestami obywatelskimi, które w sposób widoczny nasiliły się po katastrofie czarnobylskiej w 1986 r.

Żadnemu z ugrupowań ekologicznych powstałych na terytorium SFRJ nie udało się powtórzyć sukcesu, który stał się udziałem partii Zieloni Słowenii (Zeleni Slovenije), założonej w 1989 r. przez geografa Dušana Pluta. W atmosferze politycznej odwilży po objęciu władzy w Republice Słowenii przez Milana Kučana, Plut opublikował Zielony Manifest, w którym apelował o utworzenie partii ekologicznej, aby przeciwstawić się skutecznie zatruwaniu kraju i społeczeństwa przez niekontrolowany rozwój gospodarczy i technologiczny ${ }^{13}$. W pierwszych wolnych wyborach parlamentarnych w Słowenii (kwiecień 1990 r.), Zeleni Slovenije występujący w bloku opozycji demokratycznej DEMOS uzyskali poparcie $8,8 \%$ głosów obywateli, co pozwoliło na obsadzenie 8 z 80 miejsc w słoweńskim parlamencie ${ }^{14}$.

W znacznie trudniejszych warunkach politycznych niż w Słowenii działali chorwaccy ekolodzy. W 1986 r. powstała w Zagrzebiu w ramach Związku Młodzieży Socjalistycznej Chorwacji organizacja Svarun, określająca się jako Radna grupa za ekološke, pacifističke, feminističke i duhovne inicijative, a nawiązująca do tradycji działającego od 1969 r. Chorwackiego Towarzystwa Ekologicznego (Hrvatsko ekološko društvo). Aktywność tej organizacji koncentrowała się na akcji petycyjnej, skierowanej przeciwko planom lokalizacji elektrowni atomowej w rejonie Zagrzebia. Niewielkie grupy ekologicznych pasjonatów działały w Zagrzebiu i w Splicie. Plany zjednoczenia organizacji ekologicznych działających na terenie Chorwacji doprowadziły do powstania w lutym 1990 r. Unii Zielonych Chorwacji (Savez Zelenih Hrvatske), ale do końca lat 90. pozostała ona zjawiskiem marginalnym na chorwackiej scenie politycznej ${ }^{15}$.

Impulsem dla serbskich inicjatyw ekologicznych stała się w pierwszej połowie lat 80 . dyskusja nad lokalizacją elektrowni atomowej na terytorium Wojwodiny ${ }^{16}$.

${ }^{13}$ K.P Horvat, A. Smrekar, M. Zorn, Environmental Thought in Slovenia, w: Environmentalism in Central and Southeastern Europe. Historical Perspectives, ed. Hrvoje Petrić, Ivana Žebec Šilj, New York \& London 2017, s. 29.

${ }^{14}$ Kolejne wybory, w roku 1992 r. pozwoliły słoweńskim ekologom na zachowanie niewielkiej reprezentacji parlamentarnej (5 mandatów), ale poparcie dla tej partii stopniowo malało, nie przekraczając $1 \%$ pod koniec dekady.

${ }^{15}$ B. Bilić, "Movementising" the Margina. Recruitment to the Anti-War Campaign of Croatia, "Narodna umjetnost - Hrvatski časopis za etnologiju i folkloristiku" 2012, nr 1, s. 46.

${ }^{16}$ Jednym z ośrodków protestów stała się wieś Mladenovo w zachodniej Wojwodinie, rozważana jako możliwa lokalizacja drugiej elektrowni atomowej w Jugosławii - zob. Z. Oštrić, Ekološki pokret 
W spór zaangażowali się naukowcy z Uniwersytetu Belgradzkiego - Vladimir Ajdačic, Branko Lalović i Vukasin Pavlović, którzy kilka lat później, w roku 1989 powołali do życia belgradzki Eko-Centar. W roku 1987 w Pančevie rozpoczęła działalność organizacja PEGA (Pančevacka ekološka građanska akcija), działająca w ramach Związku Młodzieży Socjalistycznej Jugosławii. Główną formą aktywności PEGA stało się organizowanie konferencji i sadzenie drzew w mieście, zaliczanym do najbardziej zanieczyszczonych w Europie ${ }^{17}$. W 1989 r. PEGA praktycznie zawiesiła swoją działalność, a jej działacze zasilili Partię Zielonych Serbii (Zelena stranka Srbije), utworzoną z inicjatywy Dragana Jovanovicia. W latach $90 . \mathrm{XX}$ w. skala poparcia dla tej partii w wyborach parlamentarnych nie przekraczała $0.5 \%$.

Tradycje macedońskiego ruchu ekologicznego sięgały roku 1972, kiedy powstało Stowarzyszenie Ekologów Socjalistycznej Republiki Macedonii (Друштво на еколозите на Соиијалистичка Република Македонија). Znacznie szerszy oddźwięk społeczny zyskała działalność organizacji Przetrwanie (Опстанок), powstałej w 1989 r. w Skopju ${ }^{18}$. Grupa organizowała demonstracje przeciwko zanieczyszczeniu środowiska i uruchomiła „zieloną linię”, która umożliwiała telefoniczne zgłaszanie zagrożeń o charakterze ekologicznym. W tym samym roku w Wełesie powstało stowarzyszenie „Vila Zora”, które koordynowało działania skierowane przeciwko największemu trucicielowi miasta - hucie cynku i ołowiu. Sukcesem organizacji stało się zmniejszenie produkcji, a w konsekwencji jej całkowite wstrzymanie. Od $1990 \mathrm{r}$. Wełes stało się ośrodkiem centralnym macedońskiego ruchu ekologicznego, a jego instytucjonalną formą stał się Ekologiczny Ruch Macedonii jako federacja siedmiu niewielkich organizacji. W środowisku macedońskich ekologów ukształtowały się dwie partie polityczne - Partia Zielonych i Macedońska Partia Zielonych, ale żadnej z nich nie udało się zdobyć mandatu w wyborach parlamentarnych w latach $90 .{ }^{19}$.

W okresie transformacji ustrojowej ugrupowania ekologiczne pojawiły się także na albańskiej scenie politycznej. Jednym z pierwszych stała się utworzona w $1991 \mathrm{r}$. Agrarna Partia Albanii (Partia Agrare e Shqipërisë) ${ }^{20}$. Partia powstała z inicjatywy naukowców i studentów, związanych z Uniwersytetem Rolniczym w Tiranie, promując ideę nowoczesnego rolnictwa i ochrony środowiska naturalnego ${ }^{21}$. W pierwszych trzech elekcjach parlamentarnych $(1991,1992,1996)$ agraryści nie uzyskali ani jed-

u Jugoslaviji, Građa za proučavanje razdoblja 1971-1991, „Socijalna ekologija: časopis za ekološku misao i sociologijska istraživanja okoline", 1992, t. 1, nr 1, s. 87.

${ }^{17}$ B. Bilić, Staying "Sane" (and Even Growing) in Times of Chaos: Serbian Anti-War Activism as a Therapy, "Antropologija" 2011/1, s. 45-65. Pančevo stało się pod koniec lat 80. także sceną dla artystycznych happeningów organizowanych przez grupę Czarny liść (Crni list).

${ }^{18}$ S. Bużarovski, A. Stojmilov, Macedonia, w: w: Environmental Problems in Eastern Europe, ed. F. W. Carter, D. Turnock, London \& New York 1996, s. 361-362.

19 Warto wspomnieć także o aktywności czarnogórskich obrońców środowiska naturalnego, którzy od lat 70. angażowali się w protesty przeciwko planom budowy elektrowni wodnej, zagrażającej rezerwatowi przyrody w dolinie Tary - szerzej zob. Z. Oštrić, op. cit., s. 83-104.

${ }^{20}$ M. Łukaszewski, op. cit., s. 267.

${ }^{21}$ A. Krasniqi, Partitë politike në Shqipëri (1920-2006), Tirana 2006, s. 343. 
nego mandatu, a poparcie dla partii nie przekraczało $0,6 \%$ oddanych głosów. Dopiero w wyborach 1997 roku ugrupowaniu udało się wprowadzić do parlamentu jednego deputowanego, a cztery lata później zdobyć trzy mandaty. Przywódca ugrupowania - Lufter Xhuveli osiągnął w roku 1998 szczyt swojej kariery politycznej stając na czele resortu rolnictwa. W latach 90. środowisko albańskich ekologów reprezentowały także dwie inne partie: Enwironmentalistyczna Partia Agrarna (Partia Agrare Ambientaliste) oraz Albańska Partia Zielonych (Partia e Gjelbër e Shqipërisë), których skala społecznego poparcia nigdy nie przekroczyła $1 \%$.

Powstające na Bałkanach partie i ugrupowania odwołujące się do haseł ekologicznych i enwironmentalistycznych stanowiły zazwyczaj zjawisko marginalne i nie zdołały wypracować dla siebie wiodącej pozycji na scenie politycznej. Wspomniane wyżej organizacje stanowiły zazwyczaj dopełnienie nowej sceny politycznej, którą skutecznie przejmowały ugrupowania opozycyjne, zintegrowane wokół postulatów obrony praw człowieka czy też przezwyciężenia kryzysu ekonomicznego. Na tym tle przypadek bułgarski wydaje się absolutnie wyjątkowy, a wiodąca pozycja ugrupowań ekologicznych jako katalizatora przemian kojarzonych z pierwszą fazą transformacji ustrojowej stanowi przypadek niepowtarzalny wśród europejskich państw komunistycznych.

Specyficzną cechą gospodarki bułgarskiej w okresie komunizmu stało się forsowanie koncepcji rozwoju przemysłu ciężkiego i chemicznego, pomimo niewielkich zasobów własnych surowców naturalnych. Podobnie jak w przypadku innych krajów Bloku Wschodniego także Bułgaria doświadczyła od lat 60. procesu transformacji ekonomicznej, której podstawowym celem było stworzenie gospodarki rolniczo-przemysłowej, w oparciu o technologie, wykorzystywane w innych krajach komunistycznych. Gwałtowna industrializacja i urbanizacja przebiegały bez uwzględnienia uwarunkowań środowiskowych i wpływu nowych zakładów przemysłowych na stan zdrowia ludności. W początkach lat 80 . władze komunistycznej Bułgarii zainicjowały szereg reform określanych pojęciem „Nowego Mechanizmu Ekonomicznego”. Nawiązywały one do reform Michaiła Gorbaczowa w ZSRR i miały znacząco zwiększyć efektywność gospodarki bułgarskiej. Wprowadzenie w ramach reform mechanizmów oszczędnościowych miało w konsekwencji oznaczać zmniejszenie nakładów na ochronę środowiska naturalnego przed zanieczyszczeniami przemysłowymi.

Symbolem rozwoju gospodarczego Bułgarii pozostały wysoce energochłonne zakłady metalurgiczne i chemiczne, wykorzystujące lokalne zasoby węgla brunatnego, a także rolnictwo zużywające ogromne ilości nawozów sztucznych i pestycydów $^{22}$. Za szczególnie groźne dla środowiska naturalnego uznawano kompleks metalurgiczny Kremikowce k. Sofii, hutę cynku i ołowiu w rejonie Kyrdżali i znajdujące się w pobliżu Płowdiwu zakłady chemiczne. Sama huta w Kremikowcach emitowała w ciągu roku do środowiska setki ton odpadów i pyłów, zawierających związki azotu i siarki oraz fenole. Rzeka Iskar w rejonie Sofii miała tak wysokie wskaźniki skażenia,

\footnotetext{
${ }^{22}$ R. Bideleux, I. Jeffries, op. cit., s. 90.
} 
że nie nadawała się do wykorzystania rolniczego, ani przemysłowego ${ }^{23}$. Na liście największych trucicieli w Bułgarii znajdowały się elektrownie węglowe: Marica-Iztok, Pernik i Gabrowo, w których nie stosowano urządzeń filtracyjnych ${ }^{24}$.

Bułgaria należała do krajów najbardziej dotkniętych skutkami katastrofy czarnobylskiej. Władze Bułgarii zareagowały z opóźnieniem na informacje o zagrożeniu, zapewniając, że poziom radiacji nie przekracza dopuszczalnych norm i nie ma przeciwwskazań, aby pić bieżącą wodę i spożywać mleko od krów pasących się na pastwiskach. Zanim wprowadzono ograniczenie poruszania się w przestrzeni publicznej dla dzieci, otrzymały one w ciągu pierwszych dwóch tygodni po katastrofie wysoką dawkę promieniowania. Mimo świadomości zagrożenia powtórzeniem katastrofy czarnobylskiej, nie cofnięto podjętej w 1981 r. decyzji o budowie drugiej elektrowni atomowej w rejonie Belene i dopiero w okresie transformacji ustrojowej udało się zatrzymać realizację projektu ${ }^{25}$. W działającej od lat 70. elektrowni w Kozłoduju doszło w ciągu pierwszych dziesięciu lat jej funkcjonowania do trzech poważnych awarii, o których nie informowano opinii publicznej, ale też nie wywołały one poważnych konsekwencji radiacyjnych ${ }^{26}$.

Symbolem katastrofy ekologicznej Bułgarii w latach 80. XX w. stało się leżące w północno-wschodniej części kraju dwustutysięczne miasto Ruse. Pierwszym trucicielem miasta był zbudowany w jego sąsiedztwie lokalny kompleks przemysłowy, w tym fabryka wykładziny podłogowej i spalarnia śmieci. Stan zdrowia mieszkańców Ruse uległ dramatycznemu pogorszeniu, kiedy w roku 1983 uruchomiono zakłady chemiczne Verachim w rumuńskim Giurgiu, a w kierunku położonego po drugiej stronie Dunaju miasta Ruse w odstępach kilkudniowych zaczęła napływać chmura gazów chloropochodnych ${ }^{27}$. Mieszkańcy miasta chodzili i spali z tamponami ochronnymi na twarzy, a dzieci masowo chorowały na astmę. W 1985 r. aż 17 \% mieszkańców miasta cierpiało na choroby układu oddechowego ${ }^{28}$. Zagrożenie zdrowia i życia miesz-

23 P. Pavlinek, J. Pickles, Environmental Transitions. Transformation and Ecological Defence in Central and Eastern Europe, London \& New York 2000, s. 150-152.

${ }^{24}$ F. W. Carter, Bulgaria, w: w: Environmental Problems in Eastern Europe, ed. F. W. Carter, D. Turnock, London \& New York 1996, s. 45.

25 Pierwszy reaktor elektrowni w Kozłoduju został uruchomiony w roku 1974, kolejne cztery w latach 1975-1993. Elektrownia produkuje 33.4 \% całości energii elektrycznej produkowanej w Bułgarii co pozwala jej eksportować energię elektryczną do krajów bałkańskich i do Turcji - T. Dąborowski, Bułgaria, w: Projekty jądrowe w Europie Środkowej i Południowo-Wschodniej. Stan i perspektywy, red. M. Gniazdowski, Warszawa 2015, s. 69-70.

${ }^{26}$ Do awarii doszło w latach 1976, 1982 i 1983. W latach 1987-1990 na terenie należącym do elektrowni doszło do 24 pożarów - M. Tejada, Bulgaria’s Democratic Consolidation and the Kozloduy Nuclear Power Plant. The Unattainability of Closure, Stuttgart 2014, s. 28-29.

27 W 1986 r. węgierskie urządzenia pomiarowe zainstalowane w Ruse wykazywały 128-krotne przekroczenie dopuszczalnej normy chlorowodoru w powietrzu - zob. В. Антонова, Бавно, бавно се събирахме..._втентичната гражданска енергия на русенските протести (1987-1988 г.), https://clubz. bg/90277-bavno_bavno_se_sybirahme [dostęp: 30.12.2019].

${ }^{28}$ R. Crampton, The intelligentsia, the ecology and the opposition in Bulgaria, "The World Today" 1990, t. 46, nr 2, s. 24. 
kańców Ruse sprowokowało ruch migracyjny - w połowie lat 80. z miasta „uciekało” rocznie 15 tys. mieszkańców, ale władze zdecydowały się zablokować dalsze wyjazdy, z uwagi na potrzeby lokalnej gospodarki ${ }^{29}$.

23 września 1987 r. przed Pomnikiem Wolności w Ruse odbywała się uroczystość przysięgi dzieci wstępujących do organizacji pionierskiej. W tym samym czasie miasto spowiła chmura żółtozielonego dymu, ale mimo tego uroczystości nie przerwano. Kilkoro dzieci zemdlało, pozostałe próbowały zasłaniać twarz pionierskimi chustami ${ }^{30}$. Pięć dni później grupa sześciu kobiet, zatrudnionych w przedsiębiorstwie Parkostroj przy konserwacji zieleni miejskiej zainicjowała akcję protestacyjną przez budynkiem komitetu miejskiego partii komunistycznej, domagając się zamknięcia fabryki trującej miasto ${ }^{31}$. Kolejne wiece w centrum Ruse budziły coraz większe zainteresowanie mieszkańców miasta, a liczba uczestników w lutym 1988 r. przekraczała dwa tysiące osób. Wśród uczestników rozprowadzano ulotki ilustrujące skalę zagrożenia ekologicznego w Ruse. Do protestu społecznego przyłączyli się lokalni artyści, dzięki którym otwarto wystawę „Ekologia Ruse 87”, stanowiące nowe forum dyskusji o kryzysie ekologicznym w mieście ${ }^{32}$. Artykuł Radenko Jordanowa opublikowany w czasopiśmie „Literaturen front” opisywał sytuację w Ruse mianem katastrofy ekologicznej, a przewodniczący Stowarzyszenia Artystów Bułgarskich Swetlin Rusew na łamach pisma „Narodna kultura” apelował do władz, aby pomogły ocalić miasto $^{33}$. Brak zdecydowanej reakcji władz na protesty mógł wynikać z przekonania, że nie mają one charakteru politycznego, a zarazem odpowiedzialność za zaistniałą sytuację w większym stopniu obciążała konto Rumunii, rządzonej przez Nicolae Ceaușescu, ${ }^{34}$.

Zarejestrowany przez ekipę telewizyjną na taśmie filmowej protest mieszkańców Ruse w listopadzie 1987 r. przed budynkiem komitetu miejskiego partii stał się podstawą filmu dokumentalnego Дишай (Oddychaj), w reżyserii Jurija Żirowa, zrealizowanego na podstawie scenariusza Georgi Awramowa. Jego premiera w sofijskim Domu Kina (8 marca 1988 r.) odegrała przełomową rolę w uświadomieniu społeczeństwa sto-

${ }^{29}$ Н. Ненов, Русе пред избор на приоритети. Локална идентичност и преход, „Годишник на Асоциация за антропология, етнология и фолклористика »Онгъл«” 2005/Special, s. 282.

30 Д. Статулов, Филмът ,Дишай“ и неговият политически контекст, https://kinoto.bg/bg/articles/filmi/filmat-dishay-i-negoviyat-politicheski-kontekst [dostęp: 30.12.2019].

${ }^{31}$ R. Krastanova, Nouveaux mouvements citoyens et nouvelle politique : le mouvement environnemental en Bulgarie entre la contestation du statuo quo et la redéfinition, ,Divinatio” 2013, nr 37, s. 180. W 2005 r. reżyser Władimir Kondow nakręcił film dokumentalny Sześć kobiet (Шест жени), z udziałem czterech żyjących uczestniczek pierwszego protestu.

32 R. Crampton, op. cit., s. 24.

33 В. Тодић, „Касно дисидентство “ у Бугарској и крај владавине Тодора Живкова 1989. године, „Годишњак за друштвену историју” 2013, nr 1, s. 41.

${ }^{34}$ W 1989 r. poziom produkcji przedsiębiorstwa Verachim spadł o połowę, a trujące opary nie docierały już do Ruse, sześć lat później rozpoczęto proces jego likwidacji - zob. przypis 27. 
licy o skali katastrofy ekologicznej Ruse ${ }^{35}$. Kilkuset uczestników sofijskiej projekcji filmu Żirowa zdecydowało się powołać do życia Obywatelski Komitet Obrony Ekologicznej Ruse (Общественият комитет за екологична защита на Русе), na czele którego stanął pisarz Georgi Miszew. Próba rejestracji stowarzyszenia została zablokowana przez sąd rejonowy okręgu błagojewskiego, jak również w procedurze odwoławczej przez sąd okręgowy w Sofii, w związku z tym Komitet utracił możliwość prowadzenia legalnej działalności publicznej ${ }^{36}$.

11 kwietnia 1989 roku w Sofii z inicjatywy działaczy Komitetu powstała organizacja o nazwie Ekogłasnost, uważana za pierwsze ugrupowanie opozycyjne powstałe na fali przemian bułgarskiej Jesieni Narodów ${ }^{37}$. Na jego czele stali Petyr Słabakow, Dimczo Sawow i Nikoła Kolew. Platforma programowa ugrupowania zawierała postulaty jawności i pełnego dostępu do informacji o stanie środowiska naturalnego, zmian w programie rozwoju gospodarczego uwzględniających czynnik środowiskowy, a także wprowadzenia studiów ekologicznych na uniwersytetach bułgarskich. Organizacja miała zachować formułę egalitarną i zdecentralizowaną. Podstawowymi formami aktywności publicznej organizacji miały stać się marsze protestacyjne i akcje petycyjne ${ }^{38}$. Ruch Ekogłasnost, który zrodził się z przesłanek ekologicznych, z czasem zaczął poszerzać swój program o kwestie ekonomiczne i postulaty demokratyzacji społeczeństwa. Postulaty ekologiczne stanowiły w tym przypadku swoisty ,parawan”, który przesłaniał inicjatywy na rzecz praw człowieka, konsekwentnie zwalczane przez władze komunistyczne. Działalność ekologiczna otwierała także bułgarskiemu ruchowi perspektywy nawiązania kontaktów z podobnymi organizacjami za granicą, co mogło stworzyć szanse upublicznienia spraw bułgarskich na arenie międzynarodowej.

Pierwsze próby organizowania wieców w Sofii przez Ekogłasnost czy też spontaniczne akcje sadzenia drzew były skutecznie blokowane przez funkcjonariuszy służby bezpieczeństwa, co ograniczało w praktyce zakres aktywności tego środowiska do kawiarnianych dyskusji. Nadzieje na poprawę sytuacji stwarzało zaproszenie do Sofii w październiku 1989 r. uczestników Międzynarodowej Konferencji Ekologicznej (Ekoforum), odbywającej się pod patronatem KBWE. Od lipca 1989 r. działacze Ekogłasnosti skoncentrowali się na przygotowaniach do wystąpienia publicznego w trakcie obrad Ekoforum $^{39}$.

35 Д. Статулов, Закъснелите премиери. Контекст и обществен резонанс, „Изкуствоведски четения" 2016, nr 2, s. 367.

${ }^{36}$ В. Антонова, op. cit.

${ }^{37}$ Inicjatorem powstania nowej organizacji, która miała przełamać bierność Komitetu miał być Hristo Smolenow, uważany za autora nazwy Ekogłasnost - Д. Кюранов, Неформалите 1987-1990, „Балканистичен Форум” 2019, nr 3, s. 69.

${ }^{38} \mathrm{H}$. Mitsuda, K. Pashev, Environmentalism as ends or means? The rise and political crisis of the environmental movement in Bulgaria, „Capitalism, Nature, Socialism” 1995, t. 6, s. 87-111.

39 Д. Кюранов, op. cit., s. 73. 
Już dwa dni przed rozpoczęciem Konferencji rozpoczęła się na ulicach Sofii akcja zbierania podpisów pod petycją dotyczącą zaniechania budowy hydroelektrowni w górach Riła, zagrażającej monastyrowi rilskiemu ${ }^{40}$. Po rozpoczęciu obrad Ekoforum, w budynku Rektoratu Uniwersytetu Sofijskiego udało się zorganizować publiczne zebranie Ekogłasnosti, w którym wzięło udział ponad tysiąc osób ${ }^{41}$. Rosnąca aktywność środowisk opozycyjnych sprowokowała zaskoczone rozwojem sytuacji władze komunistyczne do działań represyjnych. 26 października milicja zatrzymała na ulicach Sofii trzydziestu działaczy Ekogłasnosti, zbierających podpisy pod petycją. Zatrzymanych pobito, wywieziono poza miasto, a następnie uwolniono. Wobec groźby przerwania obrad Ekoforum, władze Bułgarii oficjalnie przeprosiły uczestników konferencji, a Ekogłasnost uzyskała zgodę na zorganizowanie niezależnej demonstracji w stolicy. Petycja w sprawie budowy hydroelektrowni, podpisana przez 11500 osób została wręczona przez uczestników demonstracji wiceprzewodniczącemu parlamentu - Angełowi Dimitrowowi. Manifestacja Ekogłasnosti, która odbyła się 3 listopada w centrum Sofii zgromadziła ponad 9 tysięcy uczestników i wyprzedziła zaledwie o tydzień rezygnację Todora Żiwkowa z zajmowanego stanowiska $^{42}$.

W obliczu zbliżających się wolnych wyborów parlamentarnych, grupa działaczy Ekogłasnosti, kierowana przez Aleksandra Karakaczanowa, Ljubomira Iwanowa i Solomona Pajsiego utworzyła Partię Zielonych (Зелена партия), która w styczniu 1990 r. zasiliła opozycyjny Związek Sił Demokratycznych (ZSD) ${ }^{43}$. W pierwszych wolnych wyborach (10 czerwca 1990 r.) Partia Zielonych, występująca w ramach ZSD zdobyła 17 mandatów. Po konflikcie wewnątrz partii doszło do jej podziału, czego efektem był start partii w kolejnych wyborach w nowej koalicji (ZSD - Centrum). Koalicja ta nie przekroczyła jednak progu wyborczego i nie brała udziału w podziale mandatów.

Środowisko Ekogłasnosti w roku 1990 r. podzieliły typowe dla przestrzeni postkomunistycznej spory polityczne. Część działaczy związała się ze środowiskiem „niebieskich” jak określano zwolenników ZSD, pozostali zaś wybrali opcję „,zerwoną”. Ugrupowanie, które przyjęło nazwę Klubu Politycznego „Ekogłasnost”, kierowane przez Petyra Słabakowa, przed wyborami 1994 r. zdecydowało się na przyłączenie do bloku Demokratycznej Lewicy, zdominowanego przez postkomunistyczną Socjalistyczną Partię Bułgarii. Wzrost popularności Ekogłasnosti przed wyborami w 1994 r. stał się także konsekwencją aktywności publicznej ugrupowania,

\footnotetext{
40 Projektowany zbiornik w górach Riła miał stanowić rezerwuar wody pitnej dla mieszkańców Sofii. Po protestach w 1989 r. realizację inwestycji wstrzymano - Z. Kundziewicz, Water problems of central and eastern Europe - a region in transition, "Journal-des Sciences Hydrologiques 2001", t. 46, s. 887.

41 Д. Кюранов, op. cit., s. 77.

${ }^{42}$ E.G., Frankland, Green revolutions? The role of green parties in eastern Europe's transition, 19891994, "East European Quarterly” 1995 (Jan.), s. 335.

${ }^{43}$ R. Dzhekova et al., Radicalisation in Bulgaria: Threats and Trends, Sofia 2015, s. 86.
} 
w tym protestu przeciwko wznowieniu budowy elektrowni atomowej w Belene ${ }^{44}$. Wybory zakończyły się sukcesem koalicji lewicowej, co dało Klubowi Politycznemu „Ekogłasnost” siedem mandatów. W kolejnych wyborach, przeprowadzonych po kryzysie politycznym 1997 roku KP „Ekogłasnost” po raz kolejny wystartował wspólnie z postkomunistami w koalicji Demokratyczna Lewica, nie osiągając tym razem znaczących sukcesów. Od wyborów 2001 r. postępował proces marginalizacji ugrupowań ekologicznych, którym nie udało się wprowadzić do parlamentu swoich przedstawicieli. Podpisane we wrześniu 2009 r. porozumienie trzech największych ugrupowań ekologicznych (Klub Polityczny „Ekogłasnost”, Partia Zielonych, Partia Zielonych Bułgarska Zieleń) miało ten niekorzystny trend odwrócić, ale po raz kolejny wybory zakończyły się dla tego środowiska niepowodzeniem ${ }^{45}$.

Aktywność ekologicznych ruchów społecznych wpłynęła na uchwalenie już w 1991 r. zmian legislacyjnych, realizujących, przynajmniej częściowo postulaty tego środowiska. Nowa konstytucja bułgarska, uchwalona w lipcu $1991 \mathrm{r}$. w artykule 15 zapewniała obywatelom Bułgarii prawo do życia w ,zdrowym i przyjaznym środowisku naturalnym", a zarazem zobowiązywała ich do jego ochrony. Artykuł 41 ustawy zasadniczej przyznawał obywatelom prawo do uzyskania informacji o stanie środowiska naturalnego. W tym samym roku została uchwalona przez parlament bułgarski ustawa o ochronie środowiska. Stanowiła ona ramę dla realizacji polityki środowiskowej przez rząd Bułgarii. Zgodnie z ustawą realizacja nowych inwestycji przemysłowych powinna uwzględniać uwarunkowania ekologiczne, a obowiązkiem władz stało się zbieranie informacji i monitorowanie stanu środowiska naturalnego. Widoczny spadek zainteresowania organów ustawodawczych tematyką środowiskową stał się zauważalny już w okresie rządów Filipa Dimitrowa (1991-1992), mimo iż premier sam wywodził się ze środowiska ekologów. Postępujący proces transformacji ekonomicznej eksponował działania prorozwojowe, marginalizując zarazem postulaty ochrony środowiska naturalnego. Jedynym realnym sukcesem polityki środowiskowej stało się uruchomienie w 1996 r. systemu zbierania informacji i monitorowania zagrożeń dla środowiska naturalnego, dzięki wsparciu finansowemu przez program PHARE.

Zmiany klimatyczne, których doświadczyła Bułgaria w latach 90. spowodowały redukcję zagrożeń środowiskowych, których ofiarą padło w poprzedniej dekadzie rolnictwo bułgarskie. W latach 1982-1994 południowa część kraju doświadczyła konsekwencji wieloletniej suszy. W tym czasie roczne wskaźniki opadów zmniejszyły się średnio o 10-20\%, a na terenach górskich spadek sięgał nawet $40 \%$. Konsekwencją był spadek produkcji rolnej, ale także zagrożenie deficytem wody pitnej. Wyraźna poprawa bilansu wodnego od połowy lat 90 ., ale także zmniejszenie zużycia wody przez

${ }^{44}$ F.W. Carter, D. Turnock, A Review of Environmental Issues in the Light of the Transition, w: Environmental Problems in Eastern Europe, ed. F.W. Carter, D. Turnock, London \& New York 1996, s. 238.

${ }^{45}$ M. Łukaszewski, op. cit., s. 269-270. 
doświadczające zmian własnościowych rolnictwo bułgarskie wpłynęły na marginalizację problemu wodnego, który jeszcze w początkach transformacji ustrojowej pozostawał w centrum uwagi społeczeństwa ${ }^{46}$.

W pierwszej dekadzie transformacyjnej nie udało się wyeliminować zagrożeń środowiskowych, których źródłem były przede wszystkim przedsiębiorstwa chemiczne i petrochemiczne, niedoinwestowane i korzystające nadal z przestarzałych technologii produkcji. Na liście bułgarskich trucicieli czołowe miejsca zajmował Neftochim Burgas (producent tworzyw sztucznych i chemikaliów), a także zakłady produkcji nawozów sztucznych: Polichim (z siedzibą w Warnie), Neochim w Dimitrowgradzie i Agrobiochim w Starej Zagorze. Przedsiębiorstwa te należały do kategorii wielkich i ekonomicznie nieefektywnych zakładów przemysłowych, na których opierała się gospodarka bułgarska przed 1989 r., ale ich ewentualne zamknięcie groziło gwałtownym wzrostem bezrobocia. Środki przeznaczane na restrukturyzację przemysłu chemicznego w latach 90. nie pozwalały na skuteczną redukcję zagrożeń zdrowia pracowników i ludności, mieszkającej w pobliżu zakładów chemicznych.

W latach 90. głównym obszarem zainteresowania bułgarskich ekologów stała się kwestia dalszego funkcjonowania elektrowni atomowej w Kozłoduju i kontynuacji budowy drugiego tego rodzaju obiektu w Belene. ${ }^{47}$. W akcje protestu pod hasłem „BeleNE” zaangażowały się nie tylko ugrupowania polityczne, ale także środowiska naukowe (Instytut Polityki Ekologicznej) oraz organizacje pozarządowe. Zaangażowanie polityków prawicowych w protesty BeleNE wynikało także z przekonania, że kontynuacja inwestycji sprzyja realizacji rosyjskich interesów strategicznych na terytorium Bałkanów, stanowiąc zarazem klasyczny przykład korupcji bułgarskich elit politycznych ${ }^{48}$.

W przeciwieństwie do zachodnioeuropejskiego ruchu ekologicznego, Europa Środkowo-Wschodnia nie stała się w pierwszej dekadzie transformacyjnej areną walki ugrupowań enwironmentalistycznych o władzę, a jedynie o przetrwanie, które mogła zapewnić dotacja z budżetu państwa za przekroczenie określonego progu wyborczego. Mimo rosnącego zainteresowania tematyką ochrony środowiska ze strony in-

46 J. Pickles, M. Nikolova, C. Staddon, S. Velev, Z. Mateeva and A. Popov, Bulgaria, w: Environmental Problems in East-Central Europe, ed. F. Carter, D. Turnock, London \& New York 2002, s. 305-329.

${ }^{47}$ Pod wpływem opinii międzynarodowej, obawiającej się o bezpieczeństwo czterech najdłużej funkcjonujących reaktorów elektrowni Kozłoduj, na Bułgarii wymuszono decyzję o ich stopniowym wygaszeniu. Na mocy porozumienia premiera Iwana Kostowa z Komisją Europejską z 1999 roku przedłużono jej działalność do 2007 roku. Do roku 1996 zaprzestano wydobycia uranu w trzech kopalniach działających w okresie komunizmu - D. Turnock, Environmental problems and policies in East Central Europe: A changing agenda, "GeoJournal" 2001, t. 55, nr 2/4, s. 495.

${ }^{48}$ T. Dąborowski, op. cit., s. 71. 
stytucji europejskich (w szczególności Unii Europejskiej), w których skład wchodzą również urzędnicy pochodzący z tzw. nowych państw członkowskich, programy polityczne partii ekologicznych są przez społeczeństwa Europy Środkowo-Wschodniej odrzucane, a same ugrupowania są jedynie przejściowym składnikiem systemów partyjnych tych państw ${ }^{49}$.

Można doszukiwać się szeregu przyczyn takiego zjawiska. Pierwszą, które wynika z porównania poziomu rozwoju gospodarczego społeczeństw Europy Zachodniej i Wschodniej, jest niska świadomość społeczna obywateli i nierozerwalnie z tym związana potrzeba zapewnienia bezpieczeństwa materialnego, w pierwszym rzędzie, przed bezpieczeństwem ekologicznym. Postępująca normalizacja bułgarskiej sceny politycznej znacząco zmniejszyła znaczenie środowisk radykalnych, w tym także tych, które identyfikowały się z pojęciem ekologii. Bezpartyjne ruchy obywatelskie w latach 90. nie były osadzone w praktyce działań społecznych, co więcej, niejednokrotnie postrzegano je jako powrót do doświadczeń „,wymuszonej aktywności społecznej" czasów Todora Żiwkowa. Nawiązując do opinii Galii Chimiak, odnoszącej się do aktywności obywatelskiej w pierwszej dekadzie transformacji ustrojowej bułgarski ruch ekologiczny podzielił los innych inicjatyw obywatelskich, które wyobcowały się ze społeczeństwa, doświadczając procesu, który badaczka określa mianem „governmentalisation and commercialisation" ${ }^{50}$.

Formuła anty-partii, którą reprezentowały „zielone partie” w Europie Zachodniej jako typ partii zdecentralizowanej i nieformalnej nie mogła być w pełni zrozumiała i akceptowalna w społeczeństwie, którego sposób myślenia o partii jako strukturze hierarchicznej i sformalizowanej okazał się wyjątkowo trwały w realiach postkomunistycznych. Według Radosvety Krastanovej ugrupowania ekologiczne w pierwszej dekadzie transformacyjnej nie miały większego wpływu na scenę polityczną, pogrążoną w typowym dla tego okresu sporze postkomunistów i antykomunistów i dopiero „druga zielona fala” po roku 2005 przyniosła znaczący rezonans społeczny postulatom ekologicznym. Tym razem jednak wiodącą rolę odgrywały nieformalne struktury, zwane grupami obywatelskimi oraz stowarzyszenia przyrodnicze koncentrujące się na edukacji ekologicznej i aktywnej obronie środowiska naturalnego ${ }^{51}$. Zauważalna we współczesnym życiu polityczno-społecznym fascynacja tematyką ekologiczną zdaje się wpisywać we współczesne przemiany kulturowe, a społeczna aktywność ugrupowań ekologicznych zdaje się stanowić przykład przenikania zachodnioeuropejskich

${ }^{49}$ M. Łukaszewski, Marginalizacja ugrupowań ekologicznych na scenach politycznych państw Europy Środkowo-Wschodniej w okresie transformacji ustrojowej, „Środkowoeuropejskie Studia Polityczne” 2013, nr 2, s. 260-261.

${ }^{50}$ G. Chimiak, The Dynamics of Institutionalisation of Civic Initiatives in the Context of Former Communist Countries, w: Zmiana ram. Instytucje po 1989 roku w Europie Srodkowej i na Bałkanach, red. M. Bogusławska, A. Kobylińska, S. Siedlecka, Warszawa \& Kraków 2019, s. 23-24.

${ }^{51}$ Р. Стоилова, Ф. Биери, Опазване на природата: стратифищираното обществено мнение, „Социологически проблеми” 2010, nr 3-4, s. 225-250. 
wzorców kulturowych, jak również „presji ekologicznej” wynikającej z dążenia krajów Europy Południowo-Wschodniej do integracji ze strukturami europejskimi.

W pakiecie problemów ekologicznych, które współcześnie zdominowały publiczny dyskurs dominuje sześć zagadnień: zmiany klimatyczne, zanieczyszczenie rzek i powietrza, katastrofy ekologiczne wywołane przez człowieka, klęski żywiołowe wywołane czynnikami naturalnymi, a także wpływ na zdrowie społeczeństwie środków chemicznych używanych w produktach codziennego użytku. W czasach współczesnych największą uwagę środowisk ekologicznych w poszczególnych krajach europejskich przykuwa kwestia zmian klimatycznych. Zaledwie w kilku przypadkach: Czech, Malty, Bułgarii i krajów nadbałtyckich problem zanieczyszczenia wód i powietrza pozostaje najważniejszym przedmiotem społecznej troski ${ }^{52}$. Badania opinii publicznej w Bułgarii w 1995 r. dotyczące zagrożeń środowiskowych wskazywały, że większość społeczeństwa obawiała się najbardziej skutków zatrucia wody i powietrza dla ich zdrowia. W ankiecie $34 \%$ społeczeństwa godziło się na obniżenie standardu życia, aby skutecznie chronić środowisko naturalne, 80 \% uznawało za zbyt trudne w obecnej sytuacji, aby je bronić skutecznie ${ }^{53}$.

\section{BIBLIOGRAFIA}

Antonova Veselina, Bavno, bavno se s'birahme... Avtentičnata graždanska energija na rusenskite protesti (1987-1988 g.) [Антонова Веселина, Бавно, бавно се събирахме... Автентичната гражданска енергия на русенските протести (1987-1988 г.)], https://clubz.bg/90277-bavno_bavno_se_ sybirahme [dostęp: 30.12.2019].

Antoszewski Andrzej, Partie i systemy partyjne państw Unii Europejskiej na przełomie wieków, Toruń 2009.

Bideleux Robert, Jeffries Ian, The Balkans. A Postcommunist History, London \& New York 2007.

Bilić Bojan, "Movementising” the Margina. Recruitment to the Anti-War Campaign of Croatia, "Narodna umjetnost - Hrvatski časopis za etnologiju i folkloristiku” 2012, nr 1, s. 41-59.

Bilić Bojan, Staying "Sane” (and Even Growing) in Times of Chaos: Serbian Anti-War Activism as a Therapy, "Antropologija" 2011, nr 1, s. 45-65.

Burchell Jon, The Evolution of Green Politics. Development and Change within European Green Parties, London 2002.

Chimiak Galia, The Dynamics of Institutionalisation of Civic Initiatives in the Context of Former Communist Countries, w: Zmiana ram. Instytucje po 1989 roku w Europie Środkowej i na Bałkanach, red. Magdalena Bogusławska, Anna Kobylińska, Sylwia Siedlecka, Warszawa \& Kraków 2019, s. $17-35$.

Crampton Richard, The intelligentsia, the ecology and the opposition in Bulgaria, "The World Today" 1990, t. 46 (Feb.), nr 2, s. 23-26.

Dalton Russell, Reccia Steve, Rohrschneider Robert, The Environmental Movement and Modes of Political Action, "Comparative Political Studies" 2003, t. 20, nr 10, s.1-29.

Dąbrowski Tomasz, Bułgaria, w: Projekty jądrowe w Europie Środkowej i Poludniowo-Wschodniej. Stan i perspektywy, red. Mateusz Gniazdowski, Warszawa 2015.

${ }^{52}$ H.A. van der Heijden, op. cit., s. 12.

${ }^{53}$ R. Krastanova, op. cit., s. 181. 
Demertzis Nicolas, Greens at the Periphery, w: The Green Challenge. The development of Green parties in Europe, ed. Denis Richardson, Chris Roots, London \& New York 1995.

Dzhekova Rossitza et al., Radicalisation in Bulgaria: Threats and Trends, Sofia 2015.

Environmental Problems in Eastern Europe, ed. Francis W. Carter, David Turnock, London \& New York 1996.

Frankland Erich G., Green revolutions? The role of green parties in eastern Europe's transition, 19891994, "East European Quarterly" 1995 (Jan.), s. 315-345.

Heijden van der Hein Anton, Social Movements, Public Spheres and the European Politics of the Environment Green Power Europe?, New York 2010.

Horvat Katarina P., Smrekar Aleš, Zorn Matija, Environmental Thought in Slovenia, w: Environmentalism in Central and Southeastern Europe. Historical Perspectives, red. Hrvoje Petrić, Ivana Žebec Šilj, New York \& London 2017, s. 21-34.

Karamichas John, Red and Green Facets of Political Ecology Accounting for Electoral Prospects in Greece, "Journal of Modern Greek Studies" 2008, t. 26, nr 2, s. 311-336.

Kitschelt Herbert, The Green Phenomenon in Western Party Systems, w: Environmental Politics in the International Arena. Movements, Parties, Organizations and Policy, ed. Sheldon Kamieniecki, New York 1993, s. 93-112.

Kiuranov Dejan, Neformalite 1987-1990, „Balkanističen Forum” 2019, nr 3, s. 58-90 [Кюранов Деян, Неформалите 1987-1990, „Балканистичен Форум” 2019].

Krasniqi Afrim, Partitë politike në Shqipëri (1920-2006), Tirana 2006.

Krastanova Radosveta, Nouveaux mouvements citoyens et nouvelle politique: le mouvement environnemental en Bulgarie entre la contestation du statuo quo et la redéfinition, „Divinatio” 2013, nr 37, s.177-194.

Kundzewicz Zbigniew, Water problems of central and eastern Europe - a region in transition, "Journaldes Sciences Hydrologiques" 2001, t. 46 (Dec.), s. 883-896.

Łukaszewski Marcin, Marginalizacja ugrupowań ekologicznych na scenach politycznych państw Europy Środkowo-Wschodniej w okresie transformacji ustrojowej, „Środkowoeuropejskie Studia Polityczne” 2013, nr 2, s. 259-280.

Maj Dorota, Ruch głębokiej ekologii, w: Nowe ruchy społeczne, red. Maria Malczewska-Rytko, Dorota Maj, Lublin 2017, s. 71-82.

Matczak Piotr, Problemy ekologiczne jako problemy społeczne, Poznań 2000.

Mitsuda Hisayoshi, Pashev Konstantin, Environmentalism as ends or means? The rise and political crisis of the environmental movement in Bulgaria, „Capitalism, Nature, Socialism” 1995, nr 6, s. 87-111.

Mpotetzagias Iosif, I omospondia oikologon enallaktikon: to elliniko prasino peirama, "Elliniki Epitheorisi Politikis Epistimis" 2003, (Dec.), s. 69-105 [M

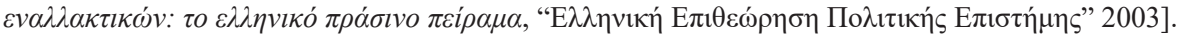

Nenov Nikolaj, Ruse pred izbor na prioriteti. Lokalna identičnost i prehod, „Godišnik na Asociacija za antropologia, etnologija i folkloristika »Ong'l《” 2005/Special, s. 280-309 [Ненов Николай, Русе пред избор на приоритети. Локална идентичност и преход, „Годишник на Асоциация за антропология, етнология и фолклористика »Онгъл«" 2005].

Oštrić Zoran, Ekološki pokret u Jugoslaviji, Građa za proučavanje razdoblja 1971-1991, „Socijalna ekologija: časopis za ekološku misao i sociologijska istraživanja okoline” 1992, t. 1, nr 1, s. 83104.

Pavlinek Petr, Pickles John, Environmental Transitions. Transformation and Ecological Defence in Central and Eastern Europe, London \& New York 2000, s.150-152.

Statulov Dejan, Fil'mt „Dišaj” i negovijat političeski kontekst [Статулов Деян, Филмът „Дишай“ и неговият политически контекст], https://kinoto.bg/bg/articles/filmi/filmat-dishay-i-negoviyat-politicheski-kontekst [dostęp: 30.12.2019].

Statulov Dejan, Zak'snelite premieri. Kontekst i obščestven rezonans, „Izkustvovedski četenija” 2016, nr 2, s. 364-369 [Статулов Деян, Закъснелите премиери. Контекст и обществен резонанс, „Изкуствоведски четения” 2016]. 
Stoilova Rumjana, Bieri Franciska, Opazvane na prirodata: stratificiranoto obščestveno mnenie, „Sociologiceski problemi” 2010, nr 3-4, s. 225-250 [Стоилова Румяна, Биери Франциска, Опазване на природата: стратифииираното обществено мнение, „Социологически проблеми" 2010].

Tejada Matthew, Bulgaria's Democratic Consolidation and the Kozloduy Nuclear Power Plant. The Unattainability of Closure, Stuttgart 2014.

Todić Vladimir, „Kasno disidenstvo“ u Bugarskoj i kraj vladavine Todora Zivkova 1989. godine, „Godišnjak za društvenu istoriju“ 2013, nr 1, s. 31-53.

Turnock David, Environmental problems and policies in East Central Europe: A changing agenda, “GeoJournal" 2001, t. 55, nr 2/4, s. 485-505. 
